\title{
Bir Açık Alan Dersliği: Kandıra Kıyıları (Kocaeli, Türkiye)
}

\author{
An Outdoor Classroom: The coasts of Kandira (Kocaeli, Turkey)
}

\begin{abstract}
Ali UZUN
Ondokuz Mayıs Üniversitesi, Fen Edebiyat Fakültesi Coğrafya Bölümü, 55270 Samsun, Türkiye (aliuzun@omu.edu.tr)
\end{abstract}

\section{ÖZ}

Türkiye kıyıları giderek artan antropojenik baskılar nedeniyle doğal özelliklerini hızla kaybetmektedir. Buna karşı1ık araştırma sahasını oluşturan Kocaeli’nin Kandıra İlçesi kıyıları bu olumsuz gidişten şimdilik korunmuş durumdadır. Araştırma sahası Karadeniz sahili boyunca batıda Pınarlı'dan doğuda Babalı Köyü’ne kadar uzanmakta ve önündeki Kefken Adası ile birlikte toplam 65 km uzunluğa sahip bulunmaktadır. Bu çalışmanın öncelikli amacı jeolojik ve jeomorfolojik miras niteliğinde çok sayıda yapı ve şekli bünyesinde barındıran Kandıra kıyılarının eğitim turizmi potansiyeline dikkat çekmek ve sürdürülebilir kullanım ilkelerine bağlı kalınarak gelecek nesillere aktarılmasına katkı yapmaktır. $\mathrm{Bu}$ amaçla çalışmada, Coğrafya lisans öğrencileri için bir "kıyı jeomorfolojisi” dersi sahadan seçilen örneklerle işlenmiştir. Çalışma hazırlanırken bir taraftan ilgili literatür incelenmiş, diğer taraftan da 2014 ve 2015 yaz aylarında saha çalışmaları gerçekleştirilmiştir. Sahada kayalık ve kumsal kıyılara ait birbirinden farklı, çok sayıda ve özgün kıyı şekli vardır. Bu şekillerden bazıları yüksek turistik albeniye sahiptir. Sahanın jeopark statüsüne kavuşturulması durumunda hem kıyının jeolojik ve jeomorfolojik miras özelliği taşıyan jeositleri daha iyi korunacak, hem de yöre insanı turizm yoluyla bu zenginliklerden daha fazla yararlanacaktır.

Anahtar Kelimeler: Jeomorfolojik miras, Jeopark, Kandıra, Karadeniz, Kıyı, Kocaeli.

\section{ABSTRACT}

The coasts of Turkey are losing their natural properties due to increasing anthropogenic pressure. The coasts of Kandira district of Kocaeli province, which is the focus of this study, have protected its natural beauty from these processes until now. The study area is located between Pinarll village on the west and Baball village on the east, and its total longshore is $65 \mathrm{~km}$ together with the Kefken Island's coasts. The main aim of this study is to stress the educational tourism potantial of Kandira coasts which have significant geological and geomorphological properties and to protect them for next generations in accordance with 
sustainable utilization principles. For this purpose, we detailed an undergraduate geography course about "coastal geomorphology" with selected forms from the study area. We realized the field works on the summer months of 2014 and 2015, and examined the literature simultaneously during the study. There are many and different typical coastal forms in the study area. Some of these already have a high tourist attraction. If the study area gains a protected status like a geopark, all of the coastal geosites will be protected and the local residents will benefit more from this wealth through tourism.

Key words: Black Sea, Coast, Geomorphological heritage, Geopark, Kandira, Kocaeli,

\section{GİRIŞ}

Eğitimde açık alan dersleri antik dönemlerden beri yapılagelmektedir. Ünlü filozof Aristo öğrencilerine yürüyerek ders anlatmasıyla bilinir (İslam Ansiklopedisi 29: 393). Coğrafya başta olmak üzere jeoloji, jeomorfoloji, biyoloji, zooloji ve ekoloji gibi birçok çevre biliminin öğretiminde arazi çalışmaları büyük önem taşır (Jonasson, 2011; Kent ve diğ. 2011; Lock, 1998). Coğrafya Lisans eğitimimiz sırasında Prof. Dr. Hayati Doğanay bize "coğrafya elle değil, ayakla yazılır" derdi. Benzer şekilde McEwan (1996) da bir eserinde "Coğrafyactlar ayaklarıyla ögrenir" demektedir.

Dünyanın diğer ülkelerinde olduğu gibi ülkemizde de coğrafya lisans eğitimi sırasında arazi uygulamaları yapılmaktadır. Nitekim halen görev yaptığım Ondokuz Mayıs Üniversitesi, Fen Edebiyat Fakültesi, Coğrafya Bölümü Lisans Programının 7 ve 8 . dönemlerinde "Arazi Tatbikatlarl-I ve Arazi Tatbikatlart-II" isimli birbirinin devamı niteliğinde iki ders okutulmaktadır. Haftada dört saat ve 6 AKTS'ye (Avrupa Kredi Transfer Sistemi) sahip bu dersler ilgili dönem başında, üniversite yönetiminin oluru ile birleştirilerek arazide yapılmaktadır. Böylece öğrenciler gerçek hayatta görerek, yaparak ve yaşayarak öğrenme imkânı bulmaktadır.
Kandıra kıyıları, İstanbul gibi dünyanın en kalabalık kentlerinden birine günübirlik ulaşım mesafesindedir. Ayrıca, yakın çevresinde Gebze, İzmit, Adapazarı ve Düzce gibi önemli kentsel yerleşmeler bulunmaktadır (Şekil 1). Bu nedenle yüksek bir öğrenci potansiyeline sahiptir. Saha, büyük kısmıyla doğal ortam özelliklerini muhafaza etmekte ve çok sayıda yüksek albenili kıyı şeklini bünyesinde barındırmaktadır. Bunların çoğu kıyı morfolojisinin farklı gelişme aşamalarını temsil etmekte ve bu nedenle de jeomorfoloji lisans öğrencileri için uygun bir uygulama alanı özelliği taşımaktadır

$\mathrm{Bu}$ çalışmanın öncelikli amacı Kandıra kıyılarının zengin jeosit varlığına dikkat çekmek ve bunların eğitim turizmi yoluyla korunarak kullanılmasına katk1 yapmaktır. Bu amaçla çalışmaya bir "Kıyı Jeomorfolojisi" dersi uygulama örneği eklenmiş ve bunun diğer açık alan uygulamaları için de denenebileceği öngörülmüştür. Sonuç olarak, sahanın zengin jeosit varlığı ve korunmuş coğrafi özellikleri bir arada değerlendirildiğinde, buranın başta coğrafya, jeoloji, biyoloji ve ekoloji gibi doğa bilimlerinin lisans öğrencileri için olmak üzere, her kademedeki öğrenciler için cazip bir uygulama alanı olabileceği değerlendirilmiştir. 


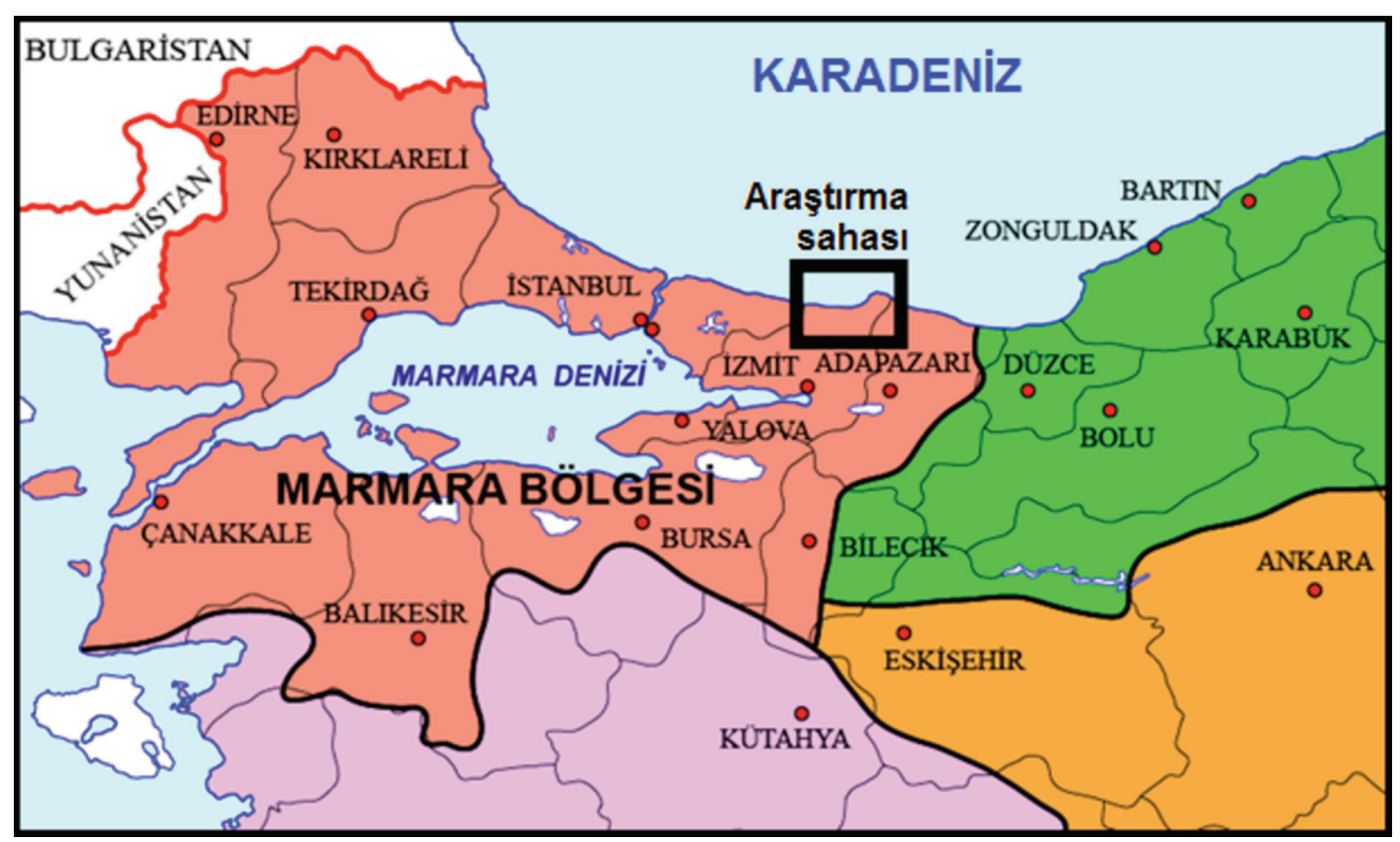

Şekil 1. Araştırma sahasının konum haritası.

Figure 1. Location map of the study area.

\section{Yöntemler}

$\mathrm{Bu}$ çalışma iki yönlü olarak yürütülmüştür. Bir taraftan literatür tarama ve değerlendirme işlemleri sürerken, diğer taraftan da arazi çalışmaları gerçekleştirilmiştir. Literatür çalışmaları sırasında başta coğrafya olmak üzere doğa bilimlerindeki açık alan ders uygulamaları incelenmiş ve elde edilen veriler uygulamadan kaynaklanan birikimlerimizle birleştirilerek birlikte değerlendirilmiştir. Arazi çalışmaları ise 2014 ve 2015 yaz aylarında yürütülmüştür. Sahadan seçilen kı1 şekilleri fotoğraflanarak dersin işlenmesinde kullanılmıştır. Çalışmayı görsel yönden zenginleştirmek için CBS tekniklerinden yararlanılmış, Global Mapper yazılımı kullanılarak sahanın sayısal yükseklik modeli haritası üretilmiştir.

\section{Bulgular}

Kandıra kıyılarının ana kayası genellikle Üst Kretase yaşlı birimlerden oluşur. Batıda ince ve orta tabakalı tortul kayalar, doğuda ise bazalt ve andezitlerden oluşan volkanik kayalar yaygındır. Ayrıca koyların içinde ve akarsu ağızlarında Kuvaterner yaşlı alüvyonlara ve eski kum depolarına rastlanır (Şekil 2).

Kandıra kıyıları jeomorfolojik özellikleri itibariyle Kefken Adası batısı ve doğusu şeklinde ikiye ayrılabilir. Kefken Adası batısında genellikle kayalık kıyılar, doğusunda ise kumsallar hâkimdir. Kayalık kıyıların egemen olduğu batı kesimde küçük koyların içinde dar alanlı kumsallara, kumsalların yaygın olduğu doğu kesimde ise dar alanlı kayalıklara rastlanır. Kıyı gerisi ise parçalı yüksek düzlüklerden oluşmaktadır. Birbirine yakın mesafelerden denize dökülen kısa boylu akarsular kıyı gerisindeki sahayı yarmış ve ana hatlarıyla bir plato görüntüsü kazandırmıştır (Şekil 3). 


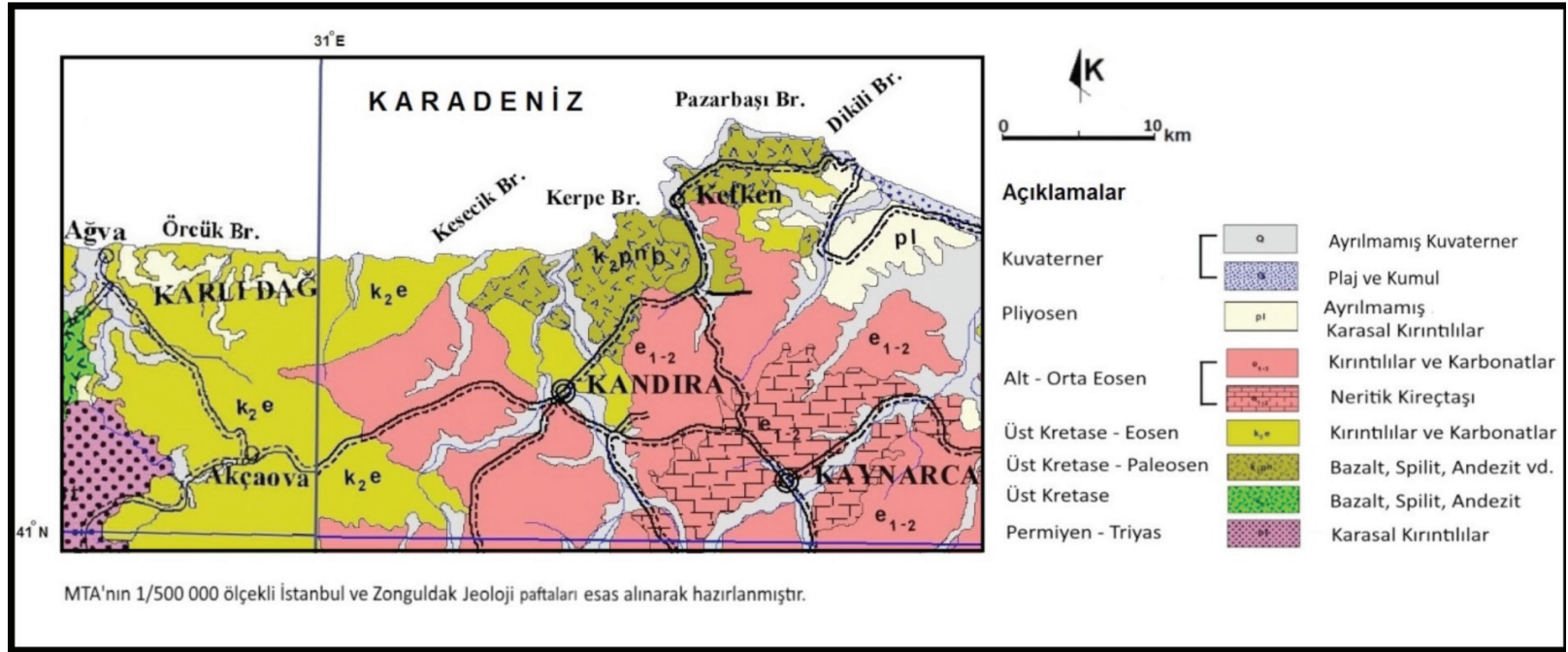

Şekil 2. Araştırma sahasının jeoloji haritası (MTA, 1/500.000 ölçekli Jeoloji haritaları, İstanbul ve Zonguldak paftaları esas alınarak hazırlanmıştır).

Figure 2. Geological map of the study area (based on MTA 1/500.000 scale geological maps, Istanbul and Zonguldak sheets.

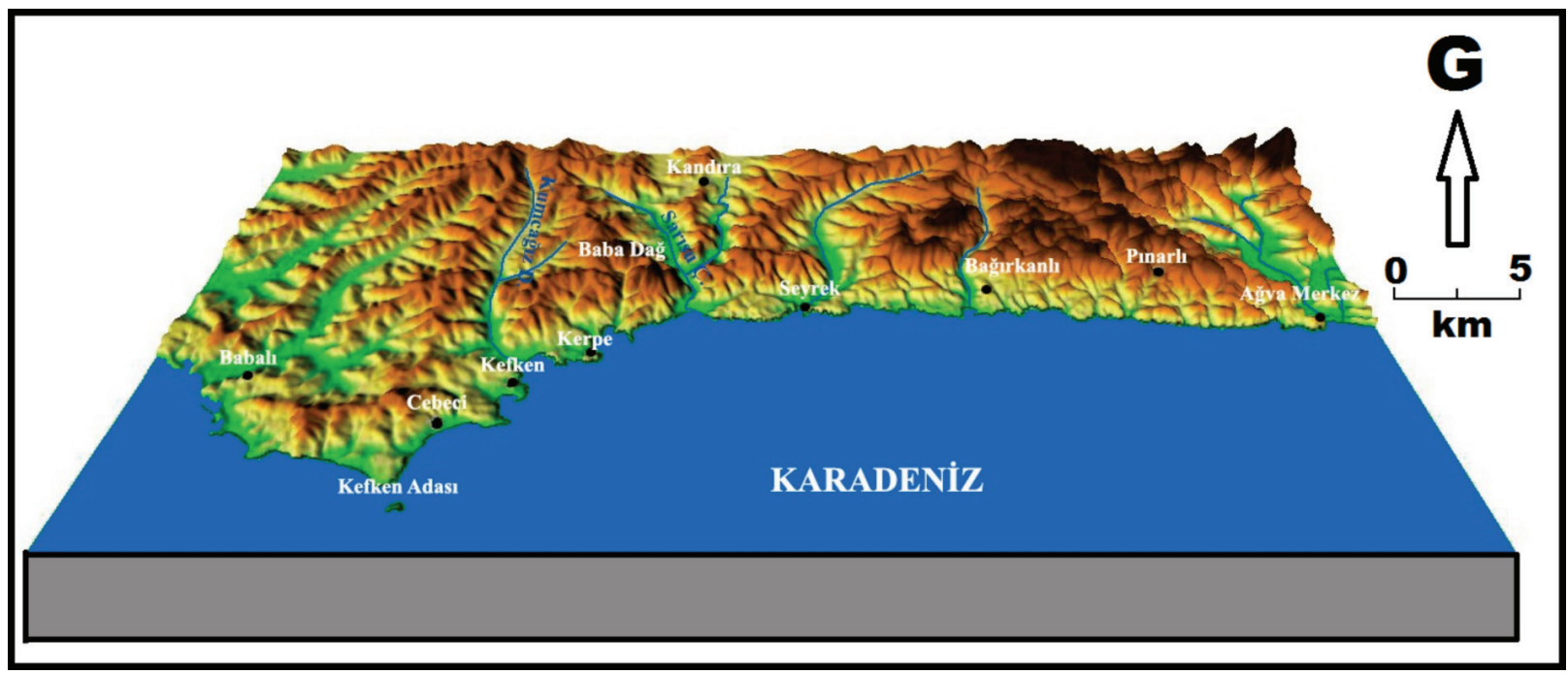

Şekil 3. Araştırma sahasının üç boyutlu haritası.

Figure 3. 3D map of the study area.

Araştırma sahasındaki kıyı şekilleri iki ana başlık altında ele alınabilir. Bunlardan birinci grubu kayalık kıyılarda dalga erozyonuyla oluşmuş şekiller, ikinci grubu ise depolanmalı kıyılarda rüzgâr hareketleriyle oluşmuş şekiller oluşturur. Kayalık kıyı şekilleri arasında abrazyon platformları, deniz mağaraları, tüneller, kemerler, parmak kayalar, kök kayalar, tafoniler, petek şekiller ve kıyı karstı şekilleri öncelikle sayılabilir. Depolanmalı kıyılarda ise enine kumul setleri, barkanlar, rüzgâr oyukları, kum gölgeleri ve kum dalgacıkları (ripple mark) dikkati çeker. Sahada ayrıca biyojenetik kıyı şekillerine de rastlanır. 


\section{Kefken Adası}

Coğrafyada ada, etrafı sularla (deniz, göl, akarsu) çevrili kara parçası olarak tanımlanır (İzbırak, 1975; Moore, 1974). Ancak çalışma sahasında olduğu gibi, bazen ada tanımına uymakla birlikte ada sayılmayan küçük adacıklar ve kayalıklar da vardır. Gerçek adaları bunlardan ayırabilmek için ada tanımını, üzerinde toprak ve bitki örtüsü gelişmiş etrafı sularla çevrili kara parçası şeklinde genişletmek gerekir. Kefken Adası, Türkiye'nin Karadeniz kıyısında yer alan iki adasından biridir. Diğeri ise Giresun Adası'dır. Kefken Adası boyutları itibariyle Giresun Adası'ndan daha büyüktür. Kıyı uzunluğu 1,7 km, yüzölçümü 0,11 $\mathrm{km}^{2}$ ve anakaraya olan uzaklığ 0,8 km'dir (Şekil 4a). Genellikle kayalık kıyılardan oluşan, ancak dar alanlı kumsallara da sahip bulunan adada tarihi dönemlerlere ait yerleşmeler bulunmaktadır. Adanın üzerinde halen faal durumda bir deniz feneri ve bazı hizmet binaları bulunmaktadır (Şekil 4b). Güneybatı tarafinda ise bir balıkçı limanı inşa edilmiştir.

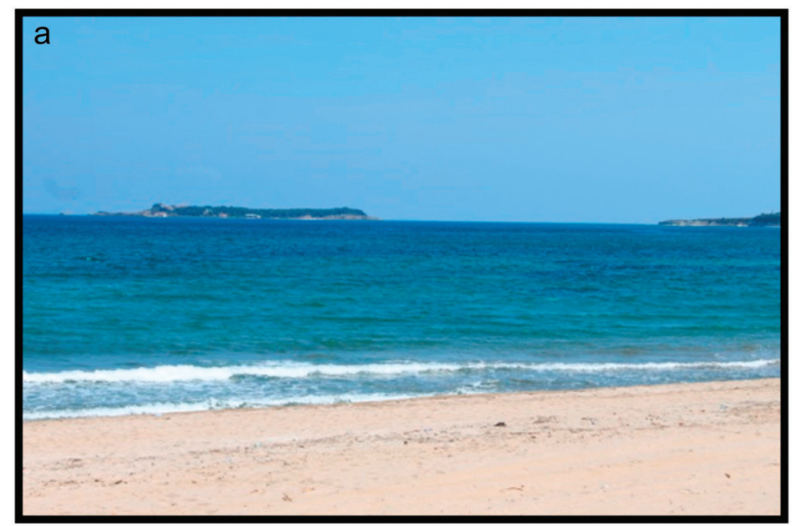

Şekil 4. Kefken Adası'ndan görüntüler. a. Kefken Adası'nın Cebeci sahilinden görünüşü. b. Kefken Adası batı burnundaki deniz feneri ve hizmet binaları.

Figure 4. The panorama of the Kefken Island. a. A general view of Kefken Island from Cebeci Beach. b. The lighthouse and service buildings at the western cape of Kefken Island. 

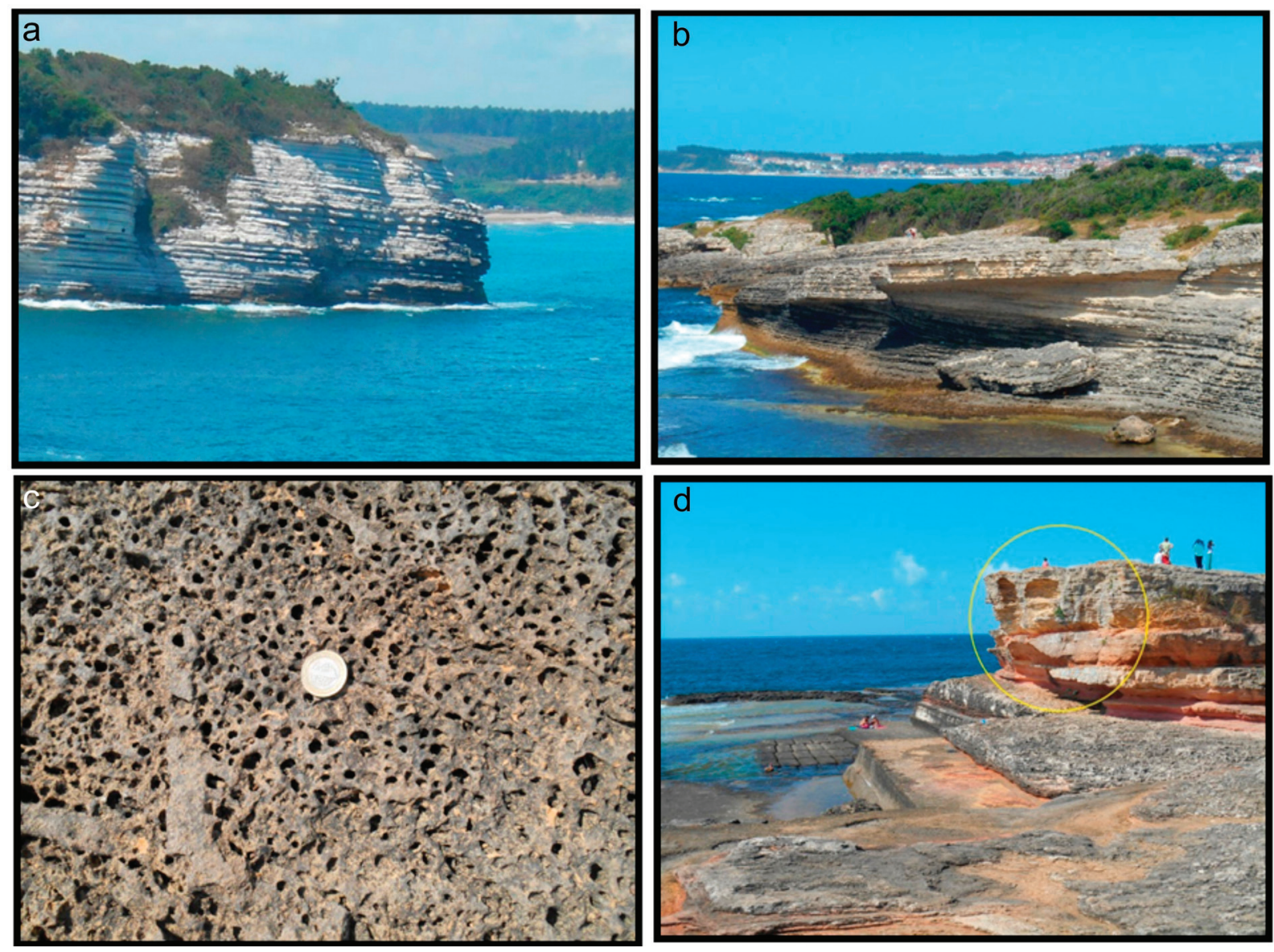

Şekil 5. Araştırma sahasındaki kayalık kıyılar. a. Güncel falezler. b. Falez gerilemesi. c. Petek şekilli çözülmeler. d. Tafoniler.

Figure 5. Rocky coasts of the study area. a. Cliffs. b. Retreating cliffs. c. Honeycombs. d. Tafoni.

Kayalık kıyılar plajlı kıyılara göre daha yavaş şekillenmekte ve sahip oldukları şekilleri daha uzun süre koruyabilmektedir. Bununla birlikte dalgaların doğrudan darbe tesirine maruz kalan falezlerin zayıf dirençli kesimleri daha hızlı aşınmakta ve özellikle de çatlak sistemleri boyunca deniz mağaraları oluşmaktadır (Şekil 6a). Burunların altından karşılıklı olarak gelişen bazı deniz mağaraları birleşerek ya da tavanları parçalar halinde çökerek kıyı tünellerine ve zamanla da kıyı kemerlerine dönüşmektedir (Şekil 6b). Daralan kıyı kemerlerinin tavanlarının çökmesiyle parmak kayalar, onların da aşınarak küçülmesiyle kök kayalar ortaya çıkmaktadır (Şekil 6c). Aşınmanın devamında ise kök kayalar da tahrip olmakta ve abrazyon platformları karaya doğru genişlemektedir (Şekil 6d). 

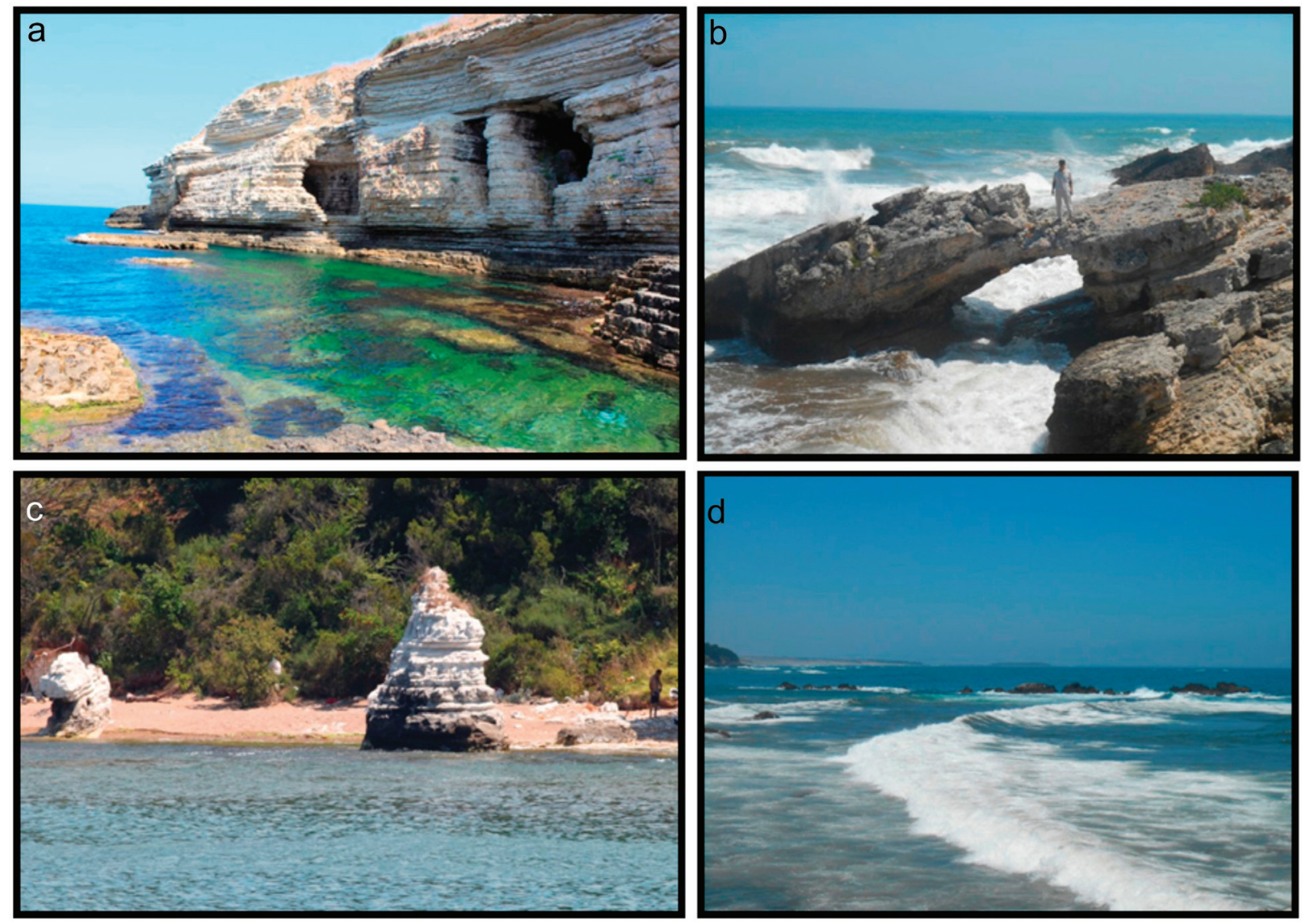

Şekil 6. Kayalık kıyıların şekillenme aşamaları: a. Falezlerin zayıf dirençli kesimlerinde gelişen deniz mağaraları. b. Deniz mağaralarının karşılıklı olarak birleşmesi ve daralmasıyla oluşan kıyı kemerleri. c. Kemerlerin tavanlarının çökmesiyle oluşmuş parmak kaya ve kök kayalar. d. Parmak kaya ve kök kayaların tahribiyle oluşmuş abrazyon platformları.

Figure 6. Formation stages of the coastal cliffs. a. Sea caves which developed in the weak resistant parts of the cliffs. $\boldsymbol{b}$. Sea arches which formed by partly colappsed the ceilings of sea cave or tunnel. c. Sea stacks and stump rocks which are formed by the collapsed ceilings of the sea arches. $\boldsymbol{d}$. The abrasion platforms which occurs after destruction of stacks and stump rocks.

\begin{abstract}
Alçak kıyılar
Alçak kıyılar burunlar arasındaki cep şekilli koylar içinde izlenirler (Şekil 7a). Basık bir arazi yapıları vardır. Genellikle kumsallardan oluşurlar. Dalga erozyonu nispeten sınırlıdır. Buna karşılık rüzgâr erozyonu etkilidir. Özellikle Cebeci batısında ve
\end{abstract}

Babalı Köyü batısında geniş kumul alanları vardır. Kıyı boyunca gelişen enine kumul sırtları yanında tipik barkan oluşumlarına da rastlanır (Şekil 7b). Burunların adeta dalgakıran gibi görev yapmaları nedeniyle yaz aylarında deniz turizmi amaciyla değerlendirilirler. 

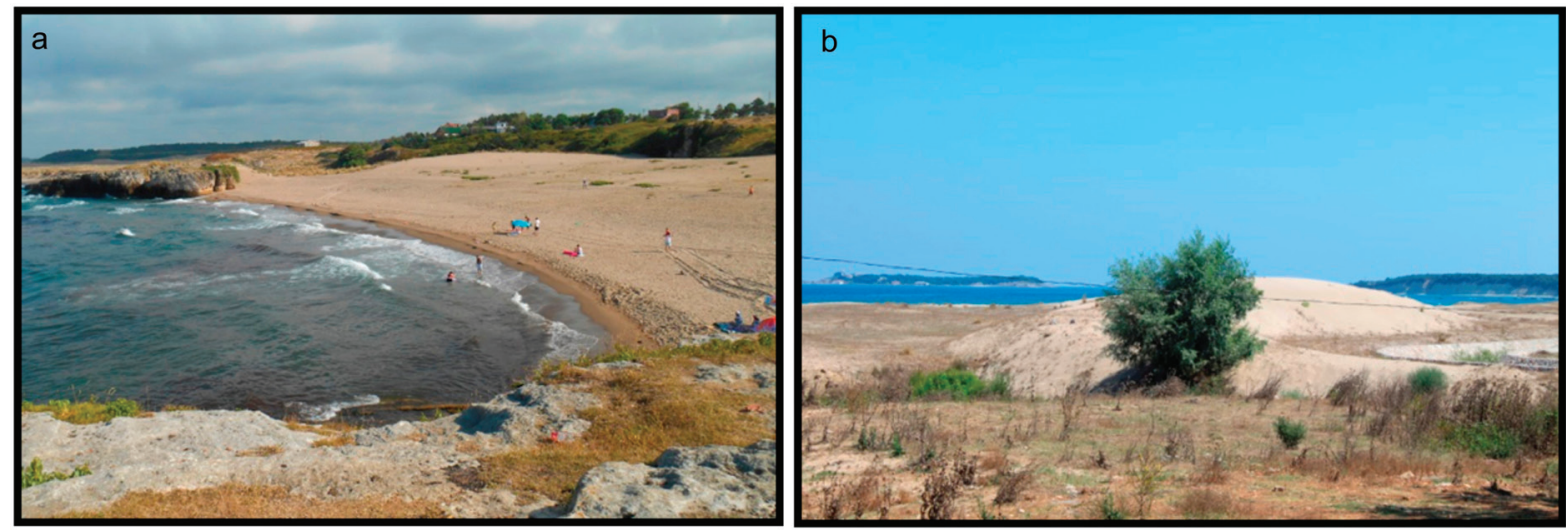

Şekil 7. Alçak kıyı ve kumsallar. a. Babalı Köyü yakınında cep şekilli bir koy ve kumsalı. b. Cebeci Köyü batısındaki kumul sahasinda bir barkan.

Figure 7. Low coast and beaches. a. A pocket bay near Babalı village. b. A barchan in the western beach of Cebeci village.

\section{SONUÇLAR VE TARTIŞMA}

Kıyılar oluşum ve görünümleri itibariyle ilginç jeositlere ev sahipliği yapar. Bunlardan jeomorfolojik özelliğiyle öne çıkanlar jeomorfosit olarak tanımlanmaktadır (Ekinci, 2010; Pereira ve diğ. 2007). Jeomorfositler son y1llarda giderek artan bir hızla turizme konu olmaktadır (Ekinci, 2010; Uzun, M. 2015). Halen dünyada kıyı kemeri, parmak kaya ve deniz mağarası gibi birçok kıyı şekli her yıl on binlerce turist tarafindan ziyaret edilmektedir (Geremia \& Massoli-Noveli, 2005; May, 2008). Ancak artan turist sayıları turizm baskısını da beraberinde getirmekte, bazen kapasite aşımı, kontrolsüz yapılaşma ve kirlenme gibi nedenlerle bu şekiller tahrip olmakta ya da çekicilikleri azalmaktadır. Sorunun giderek büyümesiyle ulusal ve uluslararası kuruluşlar devreye girmiş ve bazı koruma statüleri geliştirilmiştir. Bunlardan biri de Jeopark statüsüdür. Nitekim jeoparkların kuruluş amaçları arasında, doğal ve kültürel miras alanlarını gelecek nesiller için korumak; yer bilimleri ve çevre konularında geniş halk kitlelerinin eğitim ve ögretimine katkı yapmak, yerbilimleri için araştırma olanakları sağlamak ve turizm yoluyla sürdürülebilir kalkınmayı sağlamak gibi seçilmiş öncelikler bulunmaktadır (Eder \& Patzak, 2004).

Kandıra kıyıları son yıllarda giderek artan bir turist kitlesine ev sahipliği yapmaktadır. $\mathrm{Bu}$ nedenle daha şimdiden Bağırkanlı, Kerpe, Kefken, Cebeci ve Babalı gibi yerleşmelerin çevresinde dikkat çeken bir yapılaşma başlamıştır. Bununla birlikte Kandıra kıyıları halen doğal özelliklerini büyük kısmıyla korumaktadır. Sahada jeolojik ve jeomorfolojik miras niteliğinde çok sayıda jeosit bulunmakta ve bunların turistik önemleri giderek artmaktadır. Bu şekiller daha önce de bazı araştırmacıların ilgisini çekmiş oluşum ve turistik potansiyelleri üzerinde durulmuştur (Ertek, 1992; Uzun, A. 2015; Uzun, M. 2015). Bu çalışmada ise araştırma sahasının kıyı şekilleri coğrafya lisans öğrencileri için sistematik bir biçimde ele alınmış ve ana hatlarıyla açıklanmıştır. Böylece, başta coğrafya lisans öğrencileri olmak üzere jeoloji, ekoloji ve biyoloji gibi doğa bilimi öğrencileri için sahanın bir açık alan dersliği niteliği öne çıkarılmıştır. Sahanın İstanbul, Gebze, İzmit, 
Adapazarı ve Düzce gibi şehirlere günübirlik ulaşım mesafesinde bulunması eğitim turizmini olumlu destekleyebilir. Böylece saha bir açık alan dersliği olarak eğitime ve eğitim turizmi yoluyla da yerel kalkınmaya hizmet edebilir.

\section{EXTENDED SUMMARY}

In addition to sea tourism coasts attract crowds of tourists because of the highly attractive geomorphocites they have. However, increasing number of tourists bring the pressure of tourism, sometimes the attractions of the coasts decrease due to reasons such as overcapacity, uncontrolled settlement and pollution. The purpose of this study is to draw attention to the rich presence of geosite on the Kandira coast near enough to qualify as a day trip destination from Istanbul, one of the most populated cities in the world and contribute to their use by conserving them through educational tourism. For this purpose, a "Coastal Geomorphology" course application example has been added to the study and it can be tried out for other outdoor course applications.

This study was carried out in two ways. On one hand literature was scanned and assessment procedures continued while field studies were carried out. During the literature studies outdoor course applications starting with geography were examined and the acquired data were merged with our accumulation generated by the application and assessed together. Field studies were carried out in the summer months of 2014 and 2015. Selected coastal forms were photographed and used in the teaching of the course. Geographic Information System techniques were used to enrich the visual aspect of the study, and Global
Mapper software was used to generate a digital elevation model map.

$$
\text { In terms of geomorphological }
$$

characteristics the Kandira coast can be divided into two parts as the west and east of Kefken Island. The coast on the west side of Kefken Island is mainly rocky whereas sandy beaches dominate in the east. There are narrow beaches in small bays in the western part where rocky coasts dominate and narrow rocky areas are encountered in the eastern part where beaches dominate. The rest of the shoreline is composed of fragmented high plains. Short rivers Short rivers, reaching to the sea at close distances from each other have eroded the area behind the coastline to create an image which mainly resembles a plateau.

The coastal form of the study area can be considered under two main headings. The first group is formed by wave erosion on the rocky coast while the second group is formed by wind movements on the sandy coast. The rocky coastal forms initially include abrasion platforms, sea caves, tunnels, sea arches, sea stacks, stump rocks, tafoni, honeycomb shapes and coastal karstic formations. Transverse sand dune sets, barchans, wind gutters, sand shadows and ripple marks are noteworthy on the sandy coasts. The area also includes biogenetic coastal forms.

Interesting geosites in terms of formation and appearance are hosted on the coast. Those with geomorphological features are defined as geomorphosites and they have rapidly become a tourism subject in recent years. Currently, many shore forms such as sea arches, sea stacks and sea caves are visited by tens of thousands of tourists every year However, increasing numbers of tourists bring the pressure of tourism, and 
sometimes these forms are destroyed or their attraction is decreased due to reasons such as overcapacity, uncontrolled construction and pollution. As the problem grew, national and international organizations have become active and various protection statutes have been developed. Geoparks have such a status. As a matter of fact, the purpose of establishing geoparks is to protect natural and cultural heritage areas for future generations with selected priorities such as contribute to the education and learning to the overall public about earth sciences and environmental issues and provide research opportunities for earth sciences and ensure sustainable development through tourism.

The coast of Kandira has been the host for increasing tourist numbers in recent year. This is why a noteworthy construction activity has already started in the vicinity of settlements such as Bağırkanll, Kerpe, Kefken, Cebeci and Baball. Furthermore, the Kandira coast still retains its natural characteristics for the most part. There are numerous geosites in the area which qualify as geological and geomorphological heritages and their significance in terms of tourism continue to increase. These forms have captured the interest of various researchers previously with a focus on their formation and touristic potential. In this study, the coastal forms of the research area have been systematically addressed and outlined for undergraduate geography students. Thus, it has been emphasized that this area is an outdoor classroom for students of natural sciences such as geography, ecology and biology students and especially geography undergraduate students. The fact that the site is located within a daily transportation distance of cities like Istanbul, Gebze, Izmit, Adapazarl and Düzce can support educational tourism positively. Thus, the area can serve education as an outdoor classroom as well as local development through education and educational tourism.

\section{DEĞİNILEN BELGELER}

Eder, F. W., \& Patzak, M. 2004. Geoparks--geological attractions: A tool for public education, recreation and sustainable economic development. EpisodesNewsmagazine of the International Union of Geological Sciences, 23(3,), 162-164.

Ekinci, D. 2010. The noticeable geomorphosites of Turkey. International Journal of Arts and Sciences, 3(15), 303-321.

Ertek, T. A. (1992). Kocaeli Yarımadasının kuzeydoğu kesiminde jeomorfolojik araştırmaların sonuçları. İstanbul Üniversitesi Deniz Bilimleri ve Coğrafya Enstitüsü, Bülten, 9, 207-212.

Geremia, F., \& Massoli-Noveli, R. 2005. Coastal geomorphosites of the isles of lipari and stromboli (aeolian islands, italy): New potential for geotourism. Il Quaternario, 18(1), 233-244.

İslam Ansiklopedisi 29: http://www.islamansiklopedisi. info/dia/ayrmetin.php?idno=290393; 16.06.2016.

İzbırak, R. 1975. Coğrafya terimleri sözlüğü, MÖM Yayınları, Ankara.

Jonasson, M. 2011. Framing learning conditions in geography excursions. International Education Studies, 4(1), 21-29.

Kent, M., Gilbertson, D. D., \& Hunt, C. O. 1997. Fieldwork in geography teaching: A critical review of the literature and approaches. Journal of Geography in Higher Education, 21(3), 313- 332

Lock, R. (1998). Fieldwork in the life sciences. International Journal of Science Education, 20(6), 633-642.

May, V. (2008). Integrating the geomorphological environment, cultural heritage, tourism and 
coastal hazards in practice. Geogr. Fis. Dinam. Quat. 31, 187-194.

McEwan, L. 1996. Fieldwork in the undergraduate geography programme: Challenges and changes. Journal of Geography in Higher Education, 20(3), 379-384. doi:10.1080/03098269608709380

Moore, W. G. 1974. A dictionary of geograpy (Fifth edition ed.): Penguin Books.

Pereira, P., Pereira, D., \& Alves, M. I. (2007). Geomorphosite assessment in montesinho natural park (Portugal).

Uzun, A. 1998. Weathering forms on sandstones directly exposed to sea effects in gelincikburnu and its surroundings (South coast of the Black Sea). Zeitschrift fur Geomorphologie, 42(2), 233244.

Uzun, A. 2015. Kandıra'nın (Kocaeli) kayalık klyıları ve jeopark potansiyeli. 15-17 Ekim 2015, Ulusal Jeomorfoloji Sempozyumu, Samsun. Bildiriler Kitab1, 276-244.
Uzun, M. 2015. Kocaeli İli Karadeniz kıyılarının jeomorfoturizm özellikleri ve kıyı kullanımına etkisi açısından değerlendirilmesi. Marmara Coğrafya Dergisi, 32, 339-366.

\begin{tabular}{|c|c|}
\hline Makale Geliş Tarihi & : 26 Ağustos 2016 \\
\hline Kabul Tarihi & : 27 Aralık 2016 \\
\hline Received & : 26 August 2016 \\
\hline
\end{tabular}


